\title{
Phenotypic and molecular fingerprinting of fast growing rhizobia of field-grown pigeonpea from the eastern edge of the Brazilian Pantanal
}

\author{
F.M. Costa ${ }^{1}$, J.A. Schiavo ${ }^{1}$, M.S. Brasil ${ }^{2}$, J. Leite ${ }^{3}$, G.R. Xavier ${ }^{4}$ and \\ P.I. Fernandes $\mathbf{J r}^{5}$ \\ ${ }^{1}$ Laboratório de Matéria Orgânica e Microbiologia do Solo, \\ Departamento de Solos, Universidade Estadual do Mato Grosso do Sul, \\ Aquidauana, MS, Brasil \\ ${ }^{2}$ Laboratório de Biologia Molecular e de Micro-Organismos, \\ Departamento de Ciências do Ambiente, \\ Universidade Federal do Mato Grosso do Sul, Corumbá, MS, Brasil \\ ${ }^{3}$ Curso de Pós-Graduação em Agronomia-Ciência do Solo, \\ Departamento de Solos, Instituto de Agronomia, \\ Universidade Federal Rural do Rio de Janeiro, Seropédica, RJ, Brasil \\ ${ }^{4}$ Laboratório de Ecologia Microbiana, Embrapa Agrobiologia, \\ Seropédica, RJ, Brasil \\ ${ }^{5}$ Laboratório de Microbiologia do Solo, Embrapa Semiárido, \\ Petrolina, PE, Brasil \\ Corresponding author: P.I. Fernandes Jr \\ E-mail: paulo.ivan@embrapa.br
}

Genet. Mol. Res. 13 (1): 469-482 (2014)

Received August 22, 2013

Accepted October 26, 2013

Published January 21, 2014

DOI http://dx.doi.org/10.4238/2014.January.21.16

ABSTRACT. The aim of this study was to evaluate the diversity of rhizobial isolates obtained from root nodules of pigeonpea plants grown at the eastern edge of the Brazilian Pantanal. The bacterial isolates were isolated from root nodules from field-growing pigeonpea grown in two rural settlements of the Aquidauana municipality. The bacterial isolates were characterized phenotypically by means of 
cultural characterization, intrinsic antibiotic resistance (IAR), salt and high incubation temperature tolerance, and amylolytic and cellulolytic activities. The molecular characterization of the bacterial isolates was carried out using amplified ribosomal DNA restriction analysis (ARDRA) and Box-polymerase chain reaction (PCR) techniques. In addition, the symbiotic performance of selected rhizobial isolates was evaluated in a greenhouse experiment using sterile substrate. The phenotypic characterization revealed that the bacterial strains obtained from pigeonpea root nodules presented characteristics that are uncommon among rhizobial isolates, indicating the presence of new species nodulating the pigeonpea plants in the Brazilian Pantanal. The molecular fingerprinting of these bacterial isolates also showed a highly diverse collection, with both techniques revealing less than $25 \%$ similarity among bacterial isolates. The evaluation of symbiotic performance also indicated the presence of microorganisms with high potential to increase the growth and nitrogen content at the shoots of pigeonpea plants. The results obtained in this study indicate the presence of a highly diversified rhizobial community nodulating the pigeonpea at the eastern edge of the Brazilian Pantanal.

Key words: Biological nitrogen fixation; Diversity; Microbial ecology

\section{INTRODUCTION}

Biological nitrogen fixation (BNF) is a natural process carried out by diazotrophic bacteria, which reduces atmospheric nitrogen into ammonia through the action of the nitrogenase enzymatic complex. Among the diazotrophs, the rhizobia group can establish associations with legume plants forming root and/or stem nodules, where BNF occurs very efficiently (Sprent, 2007). The isolation and characterization of rhizobia from grain legumes such as soybean, cowpea, and common bean, have resulted in the identification of bacteria able to fix high amounts of $\mathrm{N}$ for use in improving crop nutrition and yield (Hungria et al., 2000; Martins et al., 2003). On the other hand, rhizobial isolation from other neglected crops, such as those used as green manure, is beginning in Brazil, and recent studies regarding the diversity and biotechnological applications of bacteria from green manure root nodules have shown great potential (Fernandes Jr. et al., 2010, 2011; Lima et al., 2012).

Pigeonpea (Cajanus cajan L Millsp.) is the only crop member of the Cajaninae tribe (Hancock, 2004). This species is a very rustic crop that can grow vigorously in soils with low fertility, and for this reason, is cultivated mainly in marginal lands in Brazil (Beltrame and Rodrigues, 2007). Indeed, pigeonpea is able to associate with a large diversity of indigenous rhizobia in soil, reaching more than $150 \mathrm{~kg}$ of fixed $\mathrm{N}$ per hectare per year (Peoples et al., 1995). To exploit the BNF potential of this crop, the selection and evaluation of new rhizobial strains from different areas where pigeonpea is cropped must be carried out.

The slow and fast growing pigeonpea rhizobia present great genetic and metabolic diversity and are likely to have new species among the culture collections worldwide (Ramsubhag et al., 2002; Fernandes Jr. et al., 2012). In addition to being efficient in fixing 
nitrogen in field conditions, pigeonpea rhizobia also present other biotechnological applications, such as biopolymer production and enzymatic activity (Fernandes Jr. et al., 2010, 2011, 2012).

The Brazilian Pantanal is a large floodplain covering more than $140,000 \mathrm{~km}^{2}$. Flooding is the most important ecological phenomenon and characterizes the Pantanal as a special ecological macrosystem (Abdon and Silva, 2006). Although the term "Pantanal" refers to a region with essentially hydrophyte vegetation that is common in swamps, xerophytic, and mesophytic species are also distributed in various Pantanal landscape units, with the floristic composition being influenced by the phytogeographic provinces of Cerrado, the Amazon rainforest, semi-deciduous forests, and Chaco (Damasceno-Junior et al., 2005; Oliveira, 2008). Flooding pulses can be caused by a large range of factors, such as fluctuations in the water level of the river and the local distribution of rainfall and groundwater. According to Junk and Silva (1999), the reason for flooding is very important for many flooded ecological areas, because it affects the diversity of organisms in and the nutritional status of the soil.

A non-floodable edge surrounds the floodable lands, where large municipalities, such as Corumbá and Aquidauana, are located. The phytophysiognomies of these provinces are mixed in the Pantanal wetlands, in floodable and flood-free areas, in edge areas, and in the plateaus (Scremin-Dias et al., 2011). Accordingly, evaluations of the diazotrophic bacteria associated with native species from the Pantanal have indicated the presence of a highly diverse and efficient diazotrophic community (James et al., 2001; Brasil et al., 2005), and that the flood regime influences the diversity of plant-associated diazotrophic bacteria (James et al., 2001).

Evaluations of the diversity of rhizobial strains using phenotypic characterization combined with molecular fingerprinting have revealed the great diversity in strains isolated from different Brazilian regions from cowpea (Zilli et al., 2004; Leite et al., 2009; Florentino et al., 2010), yam bean (Freitas et al., 2007), and common bean (Stocco et al., 2008). In the Brazilian Pantanal, studies evaluating the diversity of nodule-forming bacteria with phenotypic and molecular methods remain scarce in spite of the great diversity of the plant cover in the region. The aim of this study was to evaluate the phenotypic and molecular diversity of rhizobia isolated from pigeonpea root nodules from field-growing plants at the eastern edge of the Brazilian Pantanal.

\section{MATERIAL AND METHODS}

\section{Bacterial isolation}

To obtain the rhizobial isolates, field-growing pigeonpea (Cajanus cajan L. Millsp.) (cv. Caqui) was collected at two rural settlements located on the eastern edge of the Brazilian Pantanal in the Corumbá municipality, Mato Grosso do Sul State, Brazil. At the 1st collection

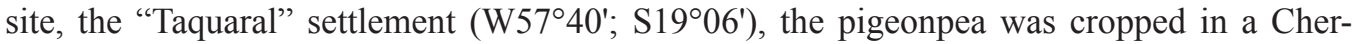
nozem soil, whereas at the "Mato Grande" settlement (W57²4'; S19 19'), the field-grown pigeonpea was collected at an Oxisol. Ten plants were collected at each site. The roots were separated from the shoots, packed in plastic bags, and transported to the laboratory.

The roots were vigorously washed with tap water, and the nodules were carefully detached and stored in glass pots with silica gel. For rhizobia isolation, the nodules were re-hydrated with sterile distilled water, disinfected superficially with $2 \% \mathrm{NaOCl}(\mathrm{v} / \mathrm{v})$, and washed 10 times with sterile distilled water (Vincent, 1970). The nodules were crushed in Petri dishes containing yeast mannitol agar (YMA) media with Congo Red (Vincent, 1970). The inocu- 
lated dishes were maintained in a growth chamber at $28^{\circ} \mathrm{C}$ for 10 days. After the incubation period, typical rhizobial cultures were purified on standard YMA media and stored at $-80^{\circ} \mathrm{C}$.

\section{Phenotypic characterization}

The cultural characteristics of pure bacterial colonies on YMA media were evaluated according to Teixeira et al. (2010). The features evaluated were $\mathrm{pH}$ reaction (neutral, acid, or alkaline), colony size ( $\mathrm{mm}$ ), colony color, and mucus production (high or low production). After the cultural characterization of the colonies, the bacterial isolates were evaluated for their growth ability at different temperatures and under increased $\mathrm{NaCl}$ content of the culture medium.

For the temperature tolerance essay, the bacterial isolates were inoculated individually on Petri dishes containing YMA media and incubated in a growth chamber at $28^{\circ} \mathrm{C}$ (control treatment), $39^{\circ}, 42^{\circ}$, and $45^{\circ} \mathrm{C}$. For the salinity assay, the bacterial isolates were inoculated on Petri dishes containing YMA media as described above. The culture medium was supplemented with $0 \mathrm{M}$ (control), $0.14 \mathrm{M}, 0.27 \mathrm{M}$, and $0.47 \mathrm{M} \mathrm{NaCl}$. The bacterial isolates were incubated in a growth chamber as described above. For both assays, the evaluation was carried out with three replications and the evaluation was performed after 3 days of incubation. The presence or absence of growth was evaluated after the incubation period, and only isolates presenting positive growth in all replications were considered to show positive growth. For isolates that presented different results among replicates, the assay was repeated to verify the characteristics.

Intrinsic antibiotic resistance (IAR) was evaluated using the double agar layer gradient method described by Bromfield et al. (1982), and modified by Xavier et al. (1998). Briefly, Petri dishes containing double YMA medium layers were prepared using low melting point agar. The bottom agar layer, supplemented with $500 \mathrm{mg} / \mathrm{L}$ kanamycin (kan), chloramphenicol (clo), or streptomycin (str), was distributed, and the culture media on the dishes were solidified on a surface with a $30^{\circ}$ incline. After basal layer solidification, the upper layer, which did not have an antibiotic supplement, was added. The antibiotic diffusion from the bottom to upper layer gave rise to three sections of antibiotic concentration: 0 to $167 \mathrm{mg} / \mathrm{L}$ (1st section), 168 to $333 \mathrm{mg} / \mathrm{L}$ (2nd section), and 334 to $500 \mathrm{mg} / \mathrm{L}$ (3rd section).

For inoculation, the bacterial isolates were grown in $250 \mathrm{~mL}$ Erlenmeyer flasks containing $100 \mathrm{~mL}$ YM liquid medium and were stirred at $105 \mathrm{rpm}$ for 3 days. One milliliter each culture broth was centrifuged ( $8000 \mathrm{x} g$ for five minutes), the supernatant was discarded, and the pellet was dissolved in $1 \mathrm{~mL}$ sterile saline solution $(0.15 \mathrm{M} \mathrm{NaCl})$. Ten microliters each cell suspension were dropped on the 1st section of Petri dishes that were inclined to drain the cell suspension toward the end of the $3 \mathrm{rd}$ section. The dishes were incubated at $28^{\circ} \mathrm{C}$ for 3 days. A score of 0 was attributed to isolates that did not present any growth (no resistance), 1 to isolates that were able to grow only on the 1 st section (low resistance), 2 to isolates that were able to grow on the 1st and 2nd sections of the dish, but were not able to grow on the 3rd section (intermediate resistance), and 3 to isolates that presented positive growth through all three zones (high resistance) (Xavier et al., 1998, Fernandes et al., 2003, Fernandes Jr. et al., 2012).

The proteolytic and amylolytic activities of all isolates were also assessed. The bacterial isolates were cultivated in YMA liquid media, and $10 \mu \mathrm{L}$ culture broth was inoculated at three equidistant points of the dish containing the appropriate substrate. The proteolytic activity was evaluated in YM medium in which the mannitol was replaced with $10 \mathrm{~g} / \mathrm{L}$ casein as the sole carbon source. The plates were incubated in a growth chamber for 4 days. To ob- 
serve the degradation zone surrounding the colonies, the plates received $5 \mathrm{~mL} 0.08 \mathrm{M}$ acetic acid. The amylolytic activity of the bacterial isolate was evaluated in YMA medium in which the mannitol was replaced with starch as the sole carbon source. The inoculated Petri dishes were incubated for 4 days and the starch degradation surrounding the colonies was observed after the addition of $5 \mathrm{~mL}$ commercial iodine solution diluted 10 times. On the basis of the enzymatic activity results, the enzymatic index resulting from the ratio between the degradation zone diameter and the colony diameter was calculated (Hankin and Anagnostakis, 1975). These assays were conducted with three replications.

The calcium phosphate solubilization assay was performed according to the procedure described by Sylvester-Bradley et al. (1982). The bacterial broth from YM medium (as described above) was inoculated in Petri dishes containing GELP medium. The plates were incubated for 6 days. For the enzymatic evaluations and the phosphate solubilization assays, the data were evaluated using analysis of variance, and means were compared by applying the Tukey test at the 5\% significance level.

\section{Molecular characterization}

Molecular fingerprinting of the bacterial isolates was carried out using the polymerase chain reaction for box elements (Box-PCR) and amplified ribosomal DNA-restriction analysis (ARDRA) techniques. For the Box-PCR, the DNA amplification was performed in a final volume of $50 \mu \mathrm{L}$ with the Box-A1 primer (TACGGCAAGGCGACGCTGACG) (Versalovic et al., 1994). The amplification was performed with an initial denaturation stage at $95^{\circ} \mathrm{C}$ for 5 min, followed by 35 cycles each of annealing $\left(55^{\circ} \mathrm{C}\right.$ for $\left.1 \mathrm{~min}\right)$, extension $\left(72^{\circ} \mathrm{C}\right.$ for $\left.3 \mathrm{~min}\right)$, and denaturation $\left(95^{\circ} \mathrm{C}\right.$ for $1 \mathrm{~min}$ ) (Hungria et al., 2000). For the horizontal electrophoresis, a $20 \times 25 \mathrm{~cm}$ cube was used, where the PCR products were applied on a $1.5 \%$ agarose gel (w/v) and submitted to $120 \mathrm{~V}$ for $8 \mathrm{~h}$, using the $1 \mathrm{~kb}$ plus DNA Leader (Invitrogen, Carlsbad, CA, USA) on each side of the gel. The gel was stained with $0.05 \%$ ethidium bromide (v/v) and visualized in an automated UV chamber.

For the ARDRA, the PCR for amplification of 16S rDNA was dimensioned to a final volume of $35 \mu \mathrm{L}$ following the recommendations of Leite et al. (2009). The universal primers used were $\mathrm{Y} 1$ and $\mathrm{Y} 3$ (Young et al., 1991). The amplification cycle consisted of an initial denaturation step of $93^{\circ} \mathrm{C}$ for $5 \mathrm{~min}$; followed by 35 cycles each of $93^{\circ} \mathrm{C}$ for $1 \mathrm{~min}, 62^{\circ} \mathrm{C}$ for $1 \mathrm{~min}$, and $72^{\circ} \mathrm{C}$ for $2 \mathrm{~min}$; and a final extension at $72^{\circ} \mathrm{C}$ for $10 \mathrm{~min}$

The restriction analysis was carried out using the restriction endonucleases DdeI, MspI, and Hinfl, and $5 \mu \mathrm{L}$ amplified DNA, according to manufacturer recommendations. The digested DNA was analyzed on $3 \%$ agarose gel (w/v) in $0.5 \%$ Tris-borate-EDTA (TBE) buffer for $3 \mathrm{~h}$ at a constant voltage of $75 \mathrm{~V}$, using the molecular weight marker $\varphi$ X174 on both sides of the gel (Invitrogen).

As reference strains for Box-PCR and ARDRA, five fast growing rhizobial strains were used: Ensifer meliloti (LMG 85217), Ensifer terangae (USDA 4894), Ensifer saheli (USDA 4893), Rhizobium etli (CFN 42), and Rhizobium leguminosarum bv. trifolii (LMG 8820). These reference strains were obtained from the diazotrophic bacteria culture collection at Embrapa Agrobiologia. The gel images were analyzed with the BioNumerics 7.0 software (Applied Maths, Kortrijk, Belgium) followed by clustering analysis to generate similarity dendrograms with the unweighted pair group method with arithmetic mean (UPGMA) and the Jaccard index. 


\section{Symbiotic efficiency}

The nodulation capacity of all bacterial isolates was assessed in a greenhouse experiment following the Koch protocol. The bacterial isolates were grown in YM liquid medium over the time required for each isolate. The pigeonpea seeds were superficially disinfected (as described for the nodules) and sown in autoclaved Leonard jars containing 2:1 sterile sand and vermiculite $(\mathrm{w} / \mathrm{v})$ as substrate. Three seeds were sown in each pot, and on the 15th day after emergence (DAE), two plants were removed, leaving only one plant per pot. The plants received water as necessary and nutritive Norris solution once a week (Norris and T'Manetje, 1964). The harvest was carried out at 60 DAE. The experiment was performed in a completely randomized design with three replications. The parameter evaluated was the presence or absence of nodules.

An experiment under greenhouse conditions was performed to evaluate the symbiotic efficiency of the selected isolates. In this assay, the bacterial isolates MFG 6, MFG 15, MFG 30, and MFG 9 from the Mato Grande settlement, and FG 9 from the Taquaral settlement were evaluated. The experiment was performed as described above. The experimental design adopted was a randomized block design with four replications. The parameters evaluated were shoot height and diameter, shoot dry matter, root dry matter, nodule number, and dry matter nitrogen accumulated at the shoot using the semi-micro method (Liao, 1981).

\section{RESULTS}

\section{Phenotypic characterization and symbiotic efficiency}

A total of 21 bacterial isolates showed the ability to nodulate the pigeonpea in the authentication experiment. Among these bacteria, the fast growing isolates presented a high diversity of cultural characteristics as shown in Table 1 . Ten isolates showed the capacity to acidify the culture medium after the growth period. Among these bacteria, nine presented large colonies (above $3 \mathrm{~mm}$ ) and a high mucus production, characteristics similar to those presented by bacteria belonging to the Rhizobium genus. The other nine isolates did not change the medium $\mathrm{pH}$, showing a neutral $\mathrm{pH}$ reaction. Each of these nine bacteria also showed colonies with diameters ranging from 1 to $3 \mathrm{~mm}$ and low mucus production, features similar to those shown by the Mesorhizobium and Methylobacterium isolates. Only three bacteria showed the capacity to increase the medium $\mathrm{pH}$, a feature that is relatively rare for fast growing rhizobial isolates.

When evaluating the complementary phenotypic characteristics, it was observed that all 21 rhizobial isolates evaluated were able to grow in YMA media with the $\mathrm{pH}$ adjusted to 9 , while approximately $50 \%$ of these bacteria were also able to grow in a medium with the $\mathrm{pH}$ decreased to 4 (Table 2). Evaluating the tolerance to high $\mathrm{NaCl}$ concentrations in the medium, only one bacterial isolate did not show the ability to grow in the salt supplemented YMA medium. Among the bacteria that grew positively in the $\mathrm{NaCl}$-added medium, three grew with $0.17 \mathrm{M} \mathrm{NaCl}$ in the medium, five grew in the $0.34 \mathrm{M} \mathrm{NaCl}$, and surprisingly, 14 bacterial isolates showed positive growth in the YMA medium supplemented with $0.52 \mathrm{M} \mathrm{NaCl}$. All evaluated bacterial isolates were able to grow in the YMA medium when an incubation temperature of $39^{\circ} \mathrm{C}$ was applied. A total of 10 isolates were 
able to grow at an incubation temperature of $45^{\circ} \mathrm{C}$, while the other nine bacterial isolates showed positive growth at $42^{\circ} \mathrm{C}$

Table 1. Cultural characteristics of 21 pigeonpea rhizobial isolates from the eastern edge of the Brazilian Pantanal.

\begin{tabular}{|c|c|c|c|c|}
\hline Rhizobial isolate & $\mathrm{pH}$ reaction & Colony size (mm) & Colony color & Mucus production \\
\hline MFG3 & Alkaline & $1-3$ & Transparent & Dry \\
\hline MFG4 & Neutral & $1-3$ & White & Low \\
\hline MFG5 & Acid & $>3$ & Transparent & High \\
\hline MFG6 & Acid & $>3$ & Creamy & High \\
\hline MFG8 & Neutral & $1-3$ & White & Low \\
\hline MFG9 & Neutral & $1-3$ & White & Low \\
\hline MFG15 & Alkaline & $1-3$ & White & Low \\
\hline MFG19 & Neutral & $1-3$ & Creamy & Low \\
\hline MFG25 & Neutral & $1-3$ & Transparent & Low \\
\hline MFG28 & Acid & $>3$ & Transparent & High \\
\hline MFG30 & Neutral & $1-3$ & White & Low \\
\hline MFG31 & Acid & $>3$ & Transparent & High \\
\hline MFG34 & Acid & $>3$ & Transparent & High \\
\hline MFG35 & Acid & $>3$ & Creamy & High \\
\hline MFG36 & Acid & $>3$ & Creamy & High \\
\hline MFG39 & Neutral & $1-3$ & Creamy & Low \\
\hline FG1 & Neutral & $1-3$ & White & Low \\
\hline FG4 & Acid & $1-3$ & Yellow & High \\
\hline FG5 & Acid & $>3$ & Transparent & High \\
\hline FG9 & Neutral & $1-3$ & Yellow & Low \\
\hline FG11 & Acid & $>3$ & Transparent & High \\
\hline
\end{tabular}

Table 2. Intrinsic antibiotic resistance, acid and alkaline $\mathrm{pH}, \mathrm{NaCl}$ concentrations and temperature tolerance of 22 pigeonpea rhizobial isolates from the eastern edge of the Brazilian Pantanal.

\begin{tabular}{|c|c|c|c|c|c|c|c|}
\hline \multirow[t]{2}{*}{ Rhizobial isolate } & \multicolumn{3}{|c|}{ Intrinsic antibiotic resistance (IAR) ${ }^{\mathrm{a}}$} & \multicolumn{2}{|c|}{$\mathrm{pH}^{\mathrm{b}}$} & \multirow[t]{2}{*}[\mathrm{NaCl}]{$^{\mathrm{c}}$} & \multirow[t]{2}{*}{ Temp..$^{\mathrm{d}}\left({ }^{\circ} \mathrm{C}\right)$} \\
\hline & Chl & Str & Kan & 4 & $\overline{9}$ & & \\
\hline MFG3 & 3 & 0 & 0 & - & + & 4 & 39 \\
\hline MFG4 & 3 & 1 & 1 & + & + & 2 & 42 \\
\hline MFG5 & 3 & 2 & 1 & - & + & 4 & 42 \\
\hline MFG6 & 2 & 1 & 0 & + & + & 4 & 45 \\
\hline MFG8 & 3 & 1 & 0 & + & + & 3 & 42 \\
\hline MFG9 & 3 & 3 & 3 & - & + & 4 & 45 \\
\hline MFG15 & 3 & 2 & 0 & + & + & 3 & 45 \\
\hline MFG19 & 1 & 0 & 0 & - & + & 4 & 42 \\
\hline MFG25 & 2 & 1 & 0 & + & + & 3 & 42 \\
\hline MFG28 & 3 & 3 & 0 & + & + & 4 & 39 \\
\hline MFG30 & 1 & 0 & 0 & + & + & 3 & 42 \\
\hline MFG31 & 2 & 1 & 1 & - & + & 2 & 42 \\
\hline MFG34 & 2 & 0 & 0 & + & + & 4 & 42 \\
\hline MFG35 & 3 & 2 & 1 & + & + & 4 & 45 \\
\hline MFG36 & 2 & 0 & 0 & + & + & 4 & 45 \\
\hline MFG39 & 1 & 0 & 0 & - & + & 4 & 45 \\
\hline FG1 & 3 & 0 & 0 & + & + & 2 & 45 \\
\hline FG4 & 2 & 3 & 0 & - & + & 4 & 42 \\
\hline FG5 & 2 & 2 & 1 & - & + & 4 & 45 \\
\hline FG9 & 0 & 0 & 0 & - & + & 1 & 39 \\
\hline FG11 & 3 & 3 & 0 & - & + & 4 & 45 \\
\hline
\end{tabular}

${ }^{a}$ Maximum IAR presented by rhizobial strains to kanamycin (kan), streptomycin (str) and chloramphenicol (chl): 0-None IAR (no resistance); 1-Low IAR (resistant until $166 \mathrm{mg} . \mathrm{L}^{-1}$ ); 2-Intermedite IAR (resistant until 333 mg.L${ }^{1}$ ); 3-High IAR (resistant until $500 \mathrm{mg} \cdot \mathrm{L}^{-1}$ ); ${ }^{\mathrm{b}}$ Growth in YMA medium with $\mathrm{pH} 4$ and $\mathrm{pH}$ 9: + = able to grow; - = unable to grow; ${ }^{\mathrm{C}}$ Maximum $\mathrm{NaCl}$ concentration in culture medium with positive grow: 1-growth only in the control without $\mathrm{NaCl}$ supplementation (1) or with $\mathrm{NaCl} 0,14$ (1); 0,27 (2) and 0,42 $\mathrm{M}$ (3); ${ }^{\mathrm{d}}$ Maximum incubation temperature with positive growth. 
Regarding the IAR, one rhizobial isolate presented high resistance to kanamycin. A total of zero, five, and 15 isolates presented intermediate, low, or no intrinsic resistance, respectively. Only four bacterial isolates presented high resistance to streptomycin, while intermediate, low, or no resistance was observed in four, six, and eight rhizobial isolates, respectively. The evaluation of IAR for chloramphenicol showed that 10 bacterial isolates presented high resistance. Seven other rhizobial isolates presented intermediate resistance, and three and two bacteria presented low or no resistance to chloramphenicol, respectively.

Among all bacterial isolates obtained in the present study, five and two presented amylolytic and proteolytic activities, respectively (Table 3 ). In the medium supplemented with starch or casein as the sole carbon source, all bacterial strains were able to grow but did not present the degradation zone around the colonies, indicating the inability of these isolates to produce extra-cellular proteolytic or amylolytic enzymes. Regarding the capacity for the solubilization of calcium phosphate, five rhizobia presented this capacity, which was observed based on the presence of the translucent zone surrounding the colonies on the GELP medium.

Table 3. Amylolytic and proteolytic activities and calcium phosphate solubilization of ten rhizobia isolated pigeonpea root nodules from the eastern edge of the Brazilian Pantanal.

\begin{tabular}{|c|c|c|c|}
\hline \multirow[t]{2}{*}{ Rhizobial isolate } & \multicolumn{2}{|c|}{ Enzymatic index $^{1}$} & \multirow{2}{*}{$\begin{array}{c}\text { Solubilization index } \\
\mathrm{Ca}\left(\mathrm{H}_{2} \mathrm{PO}_{3}\right)_{2}{ }^{3}\end{array}$} \\
\hline & Starch $^{2}$ & Casein & \\
\hline MFG3 & $1.2^{\mathrm{b}}$ & - & - \\
\hline MFG8 & - & - & $1.7^{\mathrm{b}}$ \\
\hline MFG15 & - & $1.5^{\mathrm{a}}$ & $3.1^{\mathrm{a}}$ \\
\hline MFG19 & $2.3^{\mathrm{a}}$ & - & - \\
\hline MFG25 & - & $2.0^{\mathrm{a}}$ & $3.7^{\mathrm{a}}$ \\
\hline MFG30 & $1.3^{\mathrm{b}}$ & - & - \\
\hline MFG39 & $2.0^{\mathrm{a}}$ & - & - \\
\hline MFG4 & - & - & $2.1^{\mathrm{b}}$ \\
\hline FG1 & - & - & $1.7^{\mathrm{b}}$ \\
\hline FG9 & $1.9^{\mathrm{a}}$ & - & - \\
\hline
\end{tabular}

${ }^{1}$ The enzymatic and solubilization indexes were calculated through the ration between the diameter of the degradation or solubilization zone surrounding the colony and the colony diameter (Hankin and Anagnostakis, 1975). ${ }^{2}$ Amylolytic and proteolytic activities against corn starch and casein as substrates. ${ }^{3}$ The substrate formed for the evaluation of phosphate solubilization on the GELP medium, according to Sylvester-Bradlay et al. (1982). Means in the column followed by the same letter do not differ by the Skott-Knott mean range test $(\mathrm{P}<0.05)$

Evaluating the symbiotic efficiency of the bacterial isolates, four among the five isolates tested showed some growth promotion on the pigeonpea plants. Pigeonpea plants inoculated with the bacterial isolates MFG 6, MFG 15, MFG 30, and FG 9 presented the same shoot weight and diameter observed in plants that received mineral nitrogen (Table 4). Plants inoculated with the rhizobial isolates MFG 6 and MFG 30 also presented the same shoot dry weight observed in the plants supplemented with mineral nitrogen. Surprisingly, the treatments for which the bacterial isolates MFG 15 and FG 9 were used showed higher shoot dry weight than that observed in plants that were supplied with nitrogen. Regarding the nodulation, the pigeonpea plants inoculated with the bacterial isolates MFG 15 and MFG 30 stood out with higher nodulation rates (nodule number and dry weight). In addition, the plants inoculated with the rhizobial isolate MFG 15 showed the same shoot nitrogen content as that observed in the other inoculated treatments as well as that of plants that received mineral nitrogen. 
Table 4. Symbiotic efficiency of five selected rhizobia isolated from field growing pigeonpea at the eastern edge of the Brazilian Pantanal.

\begin{tabular}{|c|c|c|c|c|c|c|c|}
\hline \multirow[t]{2}{*}{ Rhizobial isolate } & \multirow{2}{*}{$\begin{array}{c}\begin{array}{c}\text { Shoot } \\
\text { height }\end{array} \\
\mathrm{cm} \\
\end{array}$} & \multirow{2}{*}{$\begin{array}{c}\begin{array}{c}\text { Shoot } \\
\text { diameter }\end{array} \\
\mathrm{mm}\end{array}$} & $\begin{array}{l}\text { Shoot dry } \\
\text { weight }\end{array}$ & $\begin{array}{c}\text { Root dry } \\
\text { weight }\end{array}$ & \multirow{2}{*}{$\begin{array}{c}\begin{array}{c}\text { Nodule } \\
\text { number }\end{array} \\
\text { nod/pl }\end{array}$} & $\begin{array}{l}\text { Nodule dry } \\
\text { weight }\end{array}$ & $\begin{array}{r}\text { Shoot N } \\
\text { content }\end{array}$ \\
\hline & & & & & & \multicolumn{2}{|c|}{$\mathrm{mg} / \mathrm{pl}$} \\
\hline MFG 6 & $31.82^{\mathrm{a}}$ & $2.57^{\mathrm{a}}$ & $1.22^{\mathrm{b}}$ & $0.17^{\mathrm{b}}$ & $18^{\mathrm{b}}$ & $92.50^{\mathrm{b}}$ & $37.45^{\mathrm{b}}$ \\
\hline MFG 15 & $31.85^{\mathrm{a}}$ & $2.67^{\mathrm{a}}$ & $1.47^{\mathrm{a}}$ & $0.14^{\mathrm{c}}$ & $46^{\mathrm{a}}$ & $165.00^{\mathrm{a}}$ & $56.13^{\mathrm{a}}$ \\
\hline MFG 30 & $32.43^{\mathrm{a}}$ & $2.60^{\mathrm{a}}$ & $1.32^{\mathrm{b}}$ & $0.18^{\mathrm{b}}$ & $42^{\mathrm{a}}$ & $165.00^{\mathrm{a}}$ & $32.86^{\mathrm{b}}$ \\
\hline MFG 39 & $27.95^{\mathrm{b}}$ & $1.87^{\mathrm{b}}$ & $0.62^{\mathrm{c}}$ & $0.10^{\mathrm{c}}$ & $15^{\mathrm{b}}$ & $40.00^{\mathrm{c}}$ & $38.18^{\mathrm{b}}$ \\
\hline FG 9 & $36.86^{\mathrm{a}}$ & $2.70^{\mathrm{a}}$ & $1.74^{\mathrm{a}}$ & $0.21^{\mathrm{b}}$ & $20^{\mathrm{b}}$ & $100.00^{\mathrm{b}}$ & $33.09^{b}$ \\
\hline Control with $\mathrm{N}$ & $32.30^{\mathrm{a}}$ & $2.80^{\mathrm{a}}$ & $1.12^{\mathrm{b}}$ & $0.27^{\mathrm{a}}$ & $0^{\mathrm{c}}$ & $0^{\mathrm{c}}$ & $48.10^{\mathrm{a}}$ \\
\hline Control without $\mathrm{N}$ & $19.23^{\mathrm{d}}$ & $1.65^{\mathrm{b}}$ & $0.20^{\mathrm{c}}$ & $0.05^{\mathrm{b}}$ & $0^{\mathrm{c}}$ & $0^{\mathrm{c}}$ & $4.72^{\mathrm{c}}$ \\
\hline
\end{tabular}

\section{Molecular characterization}

Based on the Box-PCR profiles, all bacterial isolates and reference strains evaluated presented a similarity of only $23 \%$, and the clustering method used identified only two isolates with $100 \%$ similarity (Figure 1). A total of 11 clusters were observed of those with $70 \%$ similarity. Cluster 1 presented $74 \%$ similarity and encompassed the $R$. leguminosarum reference strains together with five other isolates from pigeonpea root nodules, including two from the Mato Grande, and three from the Taquaral settlement. Cluster two also presented $74 \%$ similarity, and was formed by one rhizobial isolate from Taquaral and two others from Mato Grande. The 3rd, 5th, 9th, and 10th clusters were single clusters, formed by only one bacterial isolate. Cluster five had only the $E$. saheli reference strain, while the other three single clusters had rhizobia from the Mato Grande settlement. The 4th cluster was formed only by the reference strains of E. fredii, E. terangae, and R. etli. Cluster six encompassed two bacterial isolates from Mato Grande with $72 \%$ similarity. Isolates FG1, MG4, and MG8 were closely clustered with 93\% similarity at the 8th cluster, and cluster 11 showed two 100\% genetically similar isolates from Mato Grande.

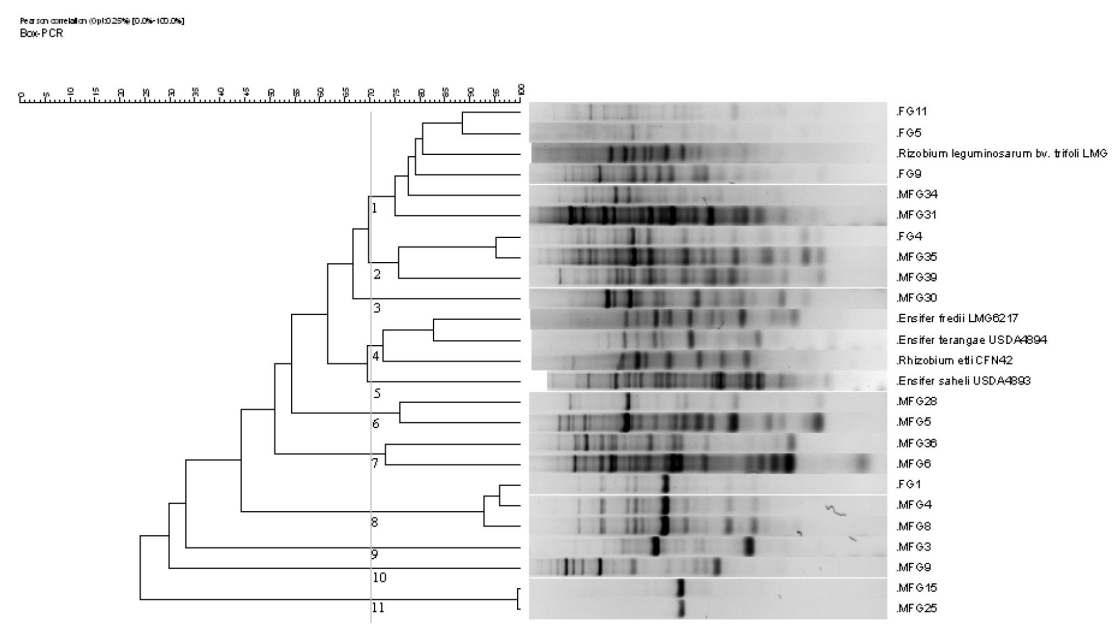

Figure 1. Genetic diversity of 21 rhizobia isolated from field growing pigeonpea at the eastern edge of the Brazilian Pantanal by the Box-PCR. Dendrogram built using the software Bionumerics and the UPGMA clustering method with the Pearson coefficient of similarity. 
The genetic diversity evaluated using the ARDRA technique showed that all bacterial isolates presented 22\% similarity (Figure 2). The clustering method at 70\% similarity formed 12 clusters. In cluster one, two rhizobial isolates from the Mato Grande settlement showed $100 \%$ similarity. The 2nd, 4th, 7th, 8th, 9th, and 11th clusters were single clusters. Among the single clusters, only the cluster eight presented a bacterial isolate from the Taquaral settlement, and the other four single clusters showed bacteria from the Mato Grande settlement. The 3rd cluster was the largest one observed during fingerprinting with the ARDRA technique. In this cluster, 10 bacterial isolates with $71 \%$ similarity were encountered, including five isolates from Mato Grande, three from Taquaral, and both Rhizobium reference strains. Cluster five presented only the Ensifer reference strains with $89 \%$ similarity. Cluster six presented two isolates from the Mato Grande settlement and one from the Taquaral settlement with $100 \%$ similarity, while cluster ten presented two rhizobia from the Mato Grande settlement with $100 \%$ similarity.

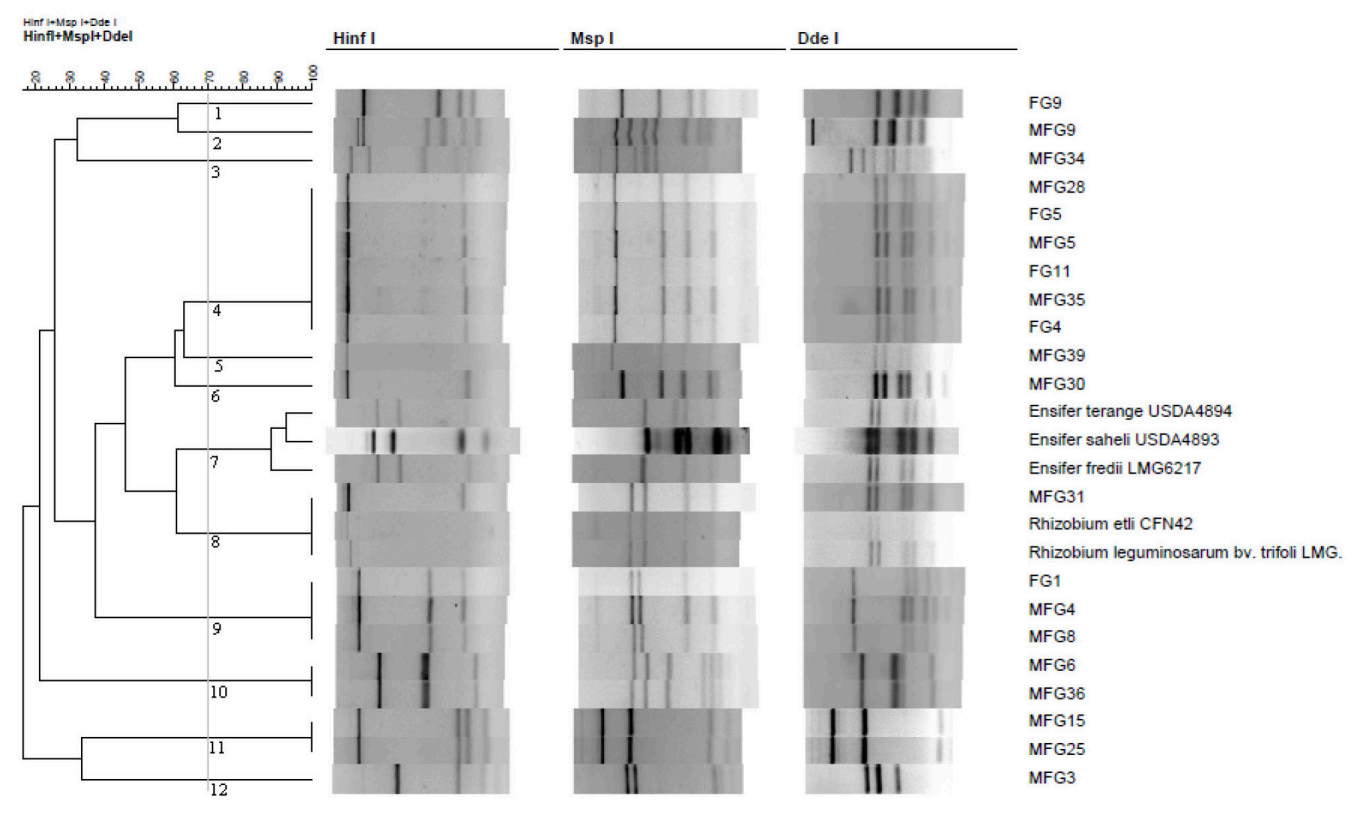

Figure 2. Genetic diversity of 21 rhizobia isolated from field growing pigeonpea at the eastern edge of the Brazilian Pantanal by ARDRA profiles using the restriction enzymes HinfI, MspI, and DdeI. Dendrogram built using the software Bionumerics and the UPGMA clustering method with the Jaccard coefficient of similarity.

\section{DISCUSSION}

Among the 21 fast growing rhizobial isolates obtained in this study, 10 bacterial isolates showed the ability to acidify the culture medium and nine did not change the medium $\mathrm{pH}$. Two isolates showed an increase of the medium $\mathrm{pH}$, which is an uncommon characteristic for fast growing rhizobial isolates. These features were also observed in some bacterial isolates obtained from tropical green manure such as pigeonpea (Fernandes Jr. et al., 2012), cowpea (Leite et al., 2009), velvet (Lima et al., 2012), and fava bean (Santos et al., 2011), which confirms the great diversity of rhizobial isolates, and most likely the existence of new taxonomic 
groups nodulating tropical green manures (Sy et al., 2001; Trujillo et al., 2005). Despite the acidification of the culture medium and the fast growth of the isolates, some rhizobial isolates shared some features characteristic of slow growing bradyrhizobial strains, such as low mucus production and transparency of the mucus. These characteristics are not exclusive for slow growing rhizobia, but are not normally observed in fast growing bacteria such as those of the Rhizobium and Ensifer genera. Leite et al. (2009) observed similar results in an evaluation of the diversity of rhizobia isolated from cowpea.

The evaluation of the rhizobial IAR showed a very peculiar pattern. In spite of the great number of isolates that presented high or intermediate resistance to chloramphenicol (17 isolates in all), this is a very uncommon characteristic for pigeonpea nodulating rhizobia (Anand and Dogra, 1991; Fernandes et al., 2003; Fernandes Jr. et al., 2012). The isolates also showed a generally low IAR for kanamycin, which is a very common characteristic for tropical rhizobia. Previous studies evaluating bacterial isolates of pigeonpea reported a generally low or intermediate resistance to chloramphenicol and a high susceptibility to kanamycin (Anand and Dogra, 1991; Fernandes et al., 2003; Fernandes Jr. et al., 2012). Other studies also showed that cowpea and common bean rhizobia also presented intermediate to low resistance to kanamycin, as was observed in the present study; however, these isolates presented a low resistance to chloramphenicol (Xavier et al., 1998; Souza et al., 2003; Zilli et al., 2004; Florentino et al., 2010). Souza et al. (2003) reported that Rhizobium tropici and E. fredii showed low resistance to chloramphenicol and to kanamycin, indicating that the majority of the bacterial isolates obtained in the present study should not belong to these species or to related groups.

Another unexpected result for the pigeonpea rhizobia assessed in this study was the relatively low resistance to streptomycin. Studies regarding the antibiotic resistance of pigeonpea rhizobia found that the majority of these bacterial isolates presented an increased IAR to streptomycin (Fernandes et al., 2003; Fernandes Jr. et al., 2012). Rhizobia from other legume crops presented a variable IAR to streptomycin, ranging from low or no resistance (Zilli et al., 2004, Florentino et al., 2010) to high resistance (Xavier et al., 1998) for cowpea rhizobia, for example. Regarding the resistance of the three antibiotics evaluated, the isolate MFG 9 stood out because it presented a high resistance to all antibiotics, indicating a high capacity of these bacteria to survive in the soil and to compete with other soil bacteria, since these bacteria presented resistance to the antibiotics produced by the bacterial and fungal isolates inhabiting the soil.

The major part of the bacterial isolates evaluated showed an interesting characteristic with regard to their ability to grow in culture media with the $\mathrm{pH}$ adjusted to 4.0 or 9.0. This ability was also observed for rhizobial strains from cowpea (Mensah et al., 2006; Florentino et al., 2010) and white clover (Brose, 1994) and is desirable in the case of bacteria that can tolerate different $\mathrm{pH}$ values, especially those that are acidic, as it is more efficient for colonizing host plants in tropical soils (Choudhury et al., 2010). The same metabolic versatility was observed during the evaluation of the bacterial capacity to grow on the culture medium supplemented with different salt concentrations as the 13 bacterial isolates presented the capacity to grow on the YMA medium supplemented with $0.52 \mathrm{M} \mathrm{NaCl}$. These results are in agreement with those found in previous studies evaluating the tolerance of tropical rhizobia from pigeonpea (Fernandes et al., 2003; Fernandes Jr. et al., 2012), cowpea (Nóbrega et al., 2004; Xavier et al., 2007, Florentino et al., 2010), and lentil (Jida and Assefa, 2011).

Regarding the high temperature tolerance of rhizobia, nine of the bacterial isolates were able to grow positively at $45^{\circ} \mathrm{C}$ incubation. Few studies have indicated the capacity of 
rhizobial growth above $40^{\circ}-42^{\circ} \mathrm{C}$ because evaluations are generally carried out below this temperature range (Florentino et al., 2010; Fernandes Jr. et al., 2012). The results found in this study point to a highly tolerant rhizobial community nodulating the pigeonpea in the Brazilian Pantanal. The evaluations of the in vitro bacterial tolerance simulated environment (salinity, high temperatures, antibiotic concentrations, etc.) are relatively cheap, require little space, are not time consuming, and can feasibly be conducted with a large number of bacterial isolates (Nóbrega et al., 2004, Xavier et al., 2007). Furthermore, the correlation between these results and field responses was recently demonstrated (Indrasumunar et al., 2012), indicating the relevance of these evaluations for rhizobial strains.

The amylolytic activity of the bacteria isolates showed that the bacterial isolates MFG 19, MFG 39, and FG 9 stood out with a higher enzymatic index. Only two rhizobial isolates showed proteolytic activity. These results indicate the presence of bacterial isolates with biotechnological potential other than inoculant production. Evaluations of the biotechnological potential of rhizobia have already been carried out in several studies (Oliveira et al., 2007; Fernandes Jr. et al., 2011, 2012). The capacity to produce enzymes of industrial interest under routine laboratory conditions is desirable to reduce the costs and offer an alternative for the inoculant industry in Brazil (Fernandes Jr. et al., 2012). Another interesting characteristic observed was the calcium phosphate solubilization results, which indicated that two bacteria (MFG 15 and MFG 25) had higher solubilization indices. This feature is normally observed in bacterial isolates from pigeonpea (Souchie and Abboud, 2007) and can be exploited through the inoculation of the bacterial isolate together with non-soluble P sources.

The symbiotic efficiency evaluation showed that the bacterial isolate MFG 15 was a very efficient bacterium, presenting the same shoot nitrogen content as pigeonpea plants that received mineral nitrogen supplement. Another important characteristic observed for green manure is the high biomass production. Two bacterial isolates evaluated caused an increase in pigeonpea biomass that was higher than that observed for the nitrogen-supplied plants. These results indicate a high efficiency of the isolates obtained in the present study. The selection of bacterial isolates for inoculation in green manures in Brazil has revealed bacterial strains with this characteristic (Lima et al., 2012), which shows the importance of continuous strain selection.

The genetic fingerprinting was performed using ARDRA and Box-PCR techniques. The dendrogram of similarity revealed 12 clusters with $70 \%$ similarity. Using the Box-PCR technique, the clustering provided 11 clusters with $70 \%$ similarity. Both techniques showed similar clustering patterns, with the majority of the bacterial isolates and reference strains belonging to the same clusters in both dendrograms. Stocco et al. (2008) observed similar results in an evaluation of the genetic diversity of common bean with both techniques. Both ARDRA and BoxPCR are feasible and inexpensive techniques that can be used to evaluate the fingerprinting of a diazotrophic bacterial collections (Zilli et al., 2004; Freitas et al., 2007; Stocco et al., 2008; Leite et al., 2009; Teixeira et al., 2010; Lima et al., 2012; Fernandes Jr. et al., 2013).

Evaluating the genetic diversity of the bacterial isolates, the same variability was observed using phenotypic characterization and molecular fingerprinting. The ARDRA and BoxPCR profiles showed that all bacterial strains evaluated had up to $25 \%$ similarity, corroborating the high genetic diversity of the bacterial isolates studied. The molecular fingerprinting of the rhizobia isolated from green manures revealed the existence of new bacteria nodulating the plants in the field (Sy et al., 2001). The results obtained in the present study also indicate the presence of new bacteria nodulating the pigeonpea in the Brazilian Pantanal. 
Recent studies evaluating the diversity of rhizobial isolates have applied phenotypic and molecular approaches to obtain better understanding of rhizobial biology and efficiency (Florentino et al., 2010; Lima et al., 2012). This approach was adopted in the present study and relevant information on the phenotypic and genetic diversity of the bacterial isolates was obtained. Further evaluations are now being carried to gain a better understanding of the taxonomic positions and efficiency of the bacterial isolates.

The 21 bacterial isolates evaluated showed great phenotypic and genetic diversity, and some isolates presented potential for further evaluations of field efficiency and biotechnological potential.

\section{REFERENCES}

Abdon MM and Silva JSV (2006). Fisionomias da Vegetação nas Sub-Regiões do Pantanal Brasileiro. São José dos Campos: INPE, Campinas: Embrapa Informática Agropecuária. 1 CD-ROM 2006.

Anand RC and Dogra RC (1991). Physiological and biochemical characteristics of fast- and slow-growing Rhizobium sp. pigeon pea (Cajanus cajan). J. Appl. Bacteriol. 70: 197-202.

Beltrame TP and Rodrigues E (2007). Feijão guandu (Cajanus cajan (L.) Millsp.) na restauração de florestas tropicais. Semina Ciênc. Agr. 28: 19-28.

Brasil MS, Baldani JI and Baldani VLD (2005). Ocorrência e diversidade de bactérias diazotróficas associadas a gramíneas forrageiras do pantanal sul matogrossense. Rev. Bras. Ciênc. Solo 29: 179-190.

Bromfield ESP, Stein M and White RP (1982). Identification of Rhizobium on antibiotic concentration gradient. Ann. Appl. Biol. 101: 269-277.

Brose E (1994). Rhizobia selection for white clover in acid soil. Pesq. Agropec. Bras. 29: 281-285.

Choudhury B, Azad P and Kalita MC (2010). Variability in symbiotic effectiveness of native Rhizobia in acid stress. Curr. Microbiol. 61: 85-91.

Damasceno-Junior GA, Semir J, Santos FAM and Leitão-Filho HF (2005). Structure, distribution of species and inundation in a riparian forest of Rio Paraguai, Pantanal, Brazil. Flora 200: 119-135.

Fernandes MF, Fernandes RPM and Hungria M (2003). Seleção de rizóbios nativos para guandu, caupi e feijão-de-porco nos tabuleiros costeiros de Sergipe. Pesq. Agropec. Bras. 38: 835-842.

Fernandes Jr PI, Almeida JPS, Passos SR and Oliveira PJ (2010). Produção e comportamento reológico de exopolissacarídeos sintetizados por rizóbios de isolados de guandu. Pesq. Agropec. Bras. 45: 1465-1470.

Fernandes Jr PI, de Oliveira PJ, Rumjanek NG and Xavier GR (2011). Poly-beta-hydroxybutyrate and exopolysaccharide biosynthesis by bacterial isolates from pigeonpea [Cajanus cajan (L.) Millsp] root nodules. Appl. Biochem. Biotechnol. 163: 473-484.

Fernandes Jr PI, Lima AA, Passos SR and Gava CAT (2012). Phenotypic diversity and amylolytic activity of fast growing rhizobia from pigeonpea [Cajanus cajan (L.) Millsp.]. Braz. J. Microbiol. 43: 1604-1612.

Fernandes Jr PI, Pereira GMD, Perin L and Silva LM (2013). Diazotrophic bacteria isolated from wild rice Oryza glumaepatula (Poaceae) in the Brazilian Amazon. Rev. Biol. Trop. 61: 991-999.

Florentino LA, Sousa PM, Silva JS and Silva KB (2010). Diversity and efficiency of Bradyrhizobium strains isolated from soil samples collected from around Sesbania virgata roots using cowpea as trap species. Rev. Bras. Ciênc. Solo 34 : 1113-1123.

Freitas ADS, Vieira CL, Santos CERS and Stamford NP (2007). Caracterização de rizóbios isolados de Jacatupé cultivado em solo salino no Estado de Pernambuco, Brasil. Bragantia 66: 497-504.

Hancock JF (2004). Plant Evolution and the Origin of Crop Species. CABI Publishing, Massachusetts.

Hankin, L.; Anagnostakis, S.L. (1975) The use of solid media for detection of enzyme production by fungi. Mycologia 16: 597-607.

Hungria M, Andrade DS, Chuerie LMO and Probanza A (2000). Isolation and characterization of new efficient and competitive bean (Phaseolus vulgaris L.) rhizobia from Brazil. Soil Biol. Biochem. 32: 1515-1528.

Hungria M, Chueire LMO, Menna P, Bangel EV (2008). Caracterização Genética de Rizóbios e Outras Bactérias Diazotróficas e Promotoras do Crescimento de Plantas por BOX-PCR. Embrapa Soja, Londrina.

Indrasumunar A, Menzies NW and Dart PJ (2012). Laboratory prescreening of Bradyrhizobium japonicum for low pH, Al and Mn tolerance can be used to predict their survival in acid soils. Soil Biol. Biochem. 48: 135-141.

James EK, Loureiro MD, Pott A and Pott VJ (2001). Flooding-tolerant legume symbioses from the Brazilian Pantanal. 
New Phytol. 150: 723-738.

Jida, M. and Assefa, F. (2011) Phenotypic and plant growth promoting characteristics of Rhizobium leguminosarum bv. viciae from lentil growing areas of Ethiopia. Afr. J. Microbol. Res. 5: 4133-4142.

Junk WJ and Silva CJO (1999). Conceito de Pulso de Inundação e suas Implicações Para o Pantanal do Mato Grosso. In: Anais Do II Simpósio Sobre Recursos Naturais e Sócio-Econômicos do Pantanal, Corumbá.

Leite J, Seido SL, Passos SR and Xavier GR (2009). Biodiversity of rhizobia associated with cowpea cultivars in soil of the lower half of the São Francisco River Valley. Rev. Bras. Ciênc. Solo 33: 1215-1226.

Lima AA, Fernandes Jr PI, Passos SR and Paulo FS (2012). Diversidade e capacidade simbiótica de rizóbios isolados de nódulos de mucuna-cinza e mucuna-anã. Rev. Bras. Ciênc. Solo 36: 337-348.

Martins LMV, Rangel FW, Xavier GR and Ribeiro JRA (2003). Contribution of biological nitrogen fixation to cowpea: a strategy for improving grain yield in the semi-arid region of Brazil. Biol. Fertil. Soils 38: 333-339.

Mensah JK, Esumeh F, Iyamu M and Omoifo C (2006). Effects of different salt concentrations and on growth of Rhizobium sp. and a cowpea Rhizobium association. Am.-Eur. J. Agric. Environ. Sci. 1: 198-202.

Norris DO and T'Mannetje L (1964). The symbiotic specialization of African Trifolium spp. in relation to their taxonomy and their agronomic use. East Afr. Agric. Forest. J. 29: 214-235.

Nóbrega RSA, Motta JS, Lacerda AM and Moreira FMS (2004). Tolerância de bactérias diazotróficas simbióticas à salinidade in vitro. Ciênc. Agrotec. 28: 899-905.

Oliveira AKM (2008). Pantanal - Origens e Características Gerais. In: Meio Ambiente e Produção Interdisciplinar: Sociedade, Natureza e Desenvolvimento (Oliveira AKM, Garnés SJA and Favero S, eds.). Uniderp, Campo Grande, $11-25$.

Oliveira AN, Oliveira LA, Andrade JS and Chagas AF (2007). Produção de amilase por rizóbios, usando farinha de pupunha como substrato. Ciênc. Tecnol. Alim. 27: 61-66.

Peoples MB, Herridge DF and Ladha JK (1995). Biological nitrogen fixation: An efficient source of nitrogen for sustainable agricultural production? Plant Soil 174: 3-28.

Ramsubhag A, Umaharan P and Donawa A (2002). Partial 16S rRNA gene sequence diversity and numerical taxonomy of slow growing pigeonpea (Cajanus cajan L Millsp) nodulating rhizobia. FEMS Microbiol. Lett. 216: 139-144.

Santos JO, Antunes JEL, Lyra MCCP and Araújo ASF (2011). Genetic diversity among native isolates of rhizobia from Phaseolus lunatus. Ann. Microbiol. 61: 437-444.

Scremin-Dias E, Lorenz-Lemke AP and Oliveira AK (2011). The floristic heterogeneity of the Pantanal and the occurrence of species with different adaptive strategies to water stress. Braz. J. Biol. 71: 275-282.

Souchie EL and Abboud ACS (2007). Solubilização de fosfato por microrganismos rizósféricos de genótipos de guandu cultivados em diferentes classes de solo. Semina Ciênc. 28: 11-18.

Souza MFM, Vale HMM and Straliotto R (2003). Competitividade de estirpes pertencentes a diferentes espécies de rizóbio para ocupação nodular em feijoeiro (Phaseolus vulgaris L.). Rev. Agron. 37: 59-63.

Sprent JI (2007). Evolving ideas of legume evolution and diversity: a taxonomic perspective on the occurrence of nodulation. New Phytol. 174: 11-25.

Stocco P, Santos JCP, Vargas VP and Hungria M (2008). Avaliação da biodiversidade de rizóbios simbiontes do feijoeiro (Phaseolus vulgaris L.) em Santa Catarina. Rev. Bras. Ciênc. Solo. 32: 1107-1120.

Sy A, Giraud E, Jourand P, Garcia N, et al. (2001). Methylotrophic Methylobacterium bacteria nodulate and fix nitrogen in symbiosis with legumes. J. Bacteriol. 183: 214-220.

Sylvester-Bradley R, Asakawa N, La Torraca S, Magalhães FMM, Oliveira LA, Pereira RM (1982). Levantamento quantitativo de microorganismos solubilizadores de fosfato na rizosfera de gramíneas e leguminosas forrageiras na Amazônia. Acta Amazonica 12: 15-22.

Teixeira FCP, Borges WL, Xavier GR and Rumjanek NG (2010). Characterization of indigenous rhizobia from Caatinga. Braz. J. Microbiol. 41: 201-208.

Trujillo ME, Willems A, Abril A, Planchuelo AM, et al. (2005). Nodulation of Lupinus albus by strains of Ochrobactrum lupini sp. nov. Appl. Environ. Microbiol. 71: 1318-1327.

Versalovic J, Schneider M, De Bruijn FJ and Lupski JR (1994). Genomic fingerprinting of bacteria using repetitive sequence-based polymerase chain reaction. Methods Mol. Cell. Biol. 5: 25-40.

Vincent JM (1970). A Manual for the Practical Study of Root Nodule Bacteria. Blackwell Scientific Publications, Oxford.

Xavier GR, Martins LMV, Neves MCP and Rumjanek NG (1998). Edaphic factors as determinants for the distribution of intrinsic antibiotic resistance in a cowpea, rhizobia population. Biol. Fertil. Soils 27: 286-392.

Xavier GR, Martins LMV, Rumjanek NG and Neves MCP (2007) Tolerância de rizóbio de feijão-caupi à salinidade e à temperatura em condição in vitro. Caatinga 20: 1-9. 2007.

Zilli JÉ, Valisheski RR, Freire FFR and Neves MCP (2004). Assesment of cowpea rhizobium in cerrado area of northeastern Brazil. Braz. J. Microbiol. 35: 281-287. 